\title{
Configurações
}

Revista Ciências Sociais

26 | 2020

Economy and Society: politics, practices, agents, and institutions

\section{Pandemics and spill-over effects: an interview with Vincent Geloso| Pandemias e efeitos colaterais: uma entrevista com Vincent Geloso}

\section{Coordenação Editorial|Editorial Coordination}

\section{OpenEdition}

\section{Edição electrónica}

URL: http://journals.openedition.org/configuracoes/10457

DOI: 10.4000/configuracoes. 10457

ISSN: 2182-7419

\section{Editora}

Centro de Investigação em Ciências Sociais

Edição impressa

Paginação: 163-170

ISSN: 1646-5075

\section{Refêrencia eletrónica}

Coordenação Editorial|Editorial Coordination, « Pandemics and spill-over effects: an interview with Vincent Geloso| Pandemias e efeitos colaterais: uma entrevista com Vincent Geloso », Configurações [Online], 26 | 2020, posto online no dia 16 dezembro 2020, consultado o 18 dezembro 2020. URL : http://journals.openedition.org/configuracoes/10457; DOI : https://doi.org/10.4000/configuracoes. 10457 
Dominguez, Rodrigo da Costa; Rodrigues, Lisbeth; Land, Jeremy; Eloranta, Jari - Pandemics and spill-over effects: an interview with Vincent Geloso. Configurações, vol. 26, 2020, pp. 163-170.

\title{
Entrevista| Interview| Entrevue
}

\section{Pandemics and spill-over effects: an interview with Vincent Geloso}

\author{
RODRIGO DA COSTA DOMINGUEZ* \\ CICS - University of Minho \\ LISBETH RODRIGUES** \\ CSG-ISEG - University of Lisbon \\ JEREMY LAND*** \\ University of Jyväskylä and University of Helsinki \\ JARI ELORANTA**** \\ University of Helsínki
}

Pandemias e efeitos colaterais: uma entrevista com Vincent Geloso

O ano de 2020 trouxe um cenário de desafios e incertezas ao mundo globalizado, para o qual muitos (ou a maioria) de nós achávamos que estávamos preparados. A rápida disseminação da COVID-19 e o estado de pandemia tiveram impactos profundos nas sociedades, em particular nas relações económicas. Este não é, contudo, o primeiro evento da história da humanidade no que diz respeito ao desenvolvimento e propagação de uma doença a escala mundial. Dentro deste panorama, muitas questões surgiram relativamente ao impacto que um evento desta magnitude pode causar numa economia globalizada. Como é que as instituições reagem perante uma pandemia? Qual a sua capacidade de resposta? Aprendemos alguma coisa com as experiências do passado? É possível comparar este evento com outras pandemias anteriores?

Estas e outras questões foram abordadas numa entrevista com o investigador Vincent Geloso, professor de economia no King's University College (Canadá). A sua investigação tem procurado respostas sobre estas e outras questões relativas ao efeito das pandemias mundiais na economia em outros momentos da História, adotando uma perspectiva comparada. Nesta entrevista, Vicent Geloso ressalta que há diferenças importantes a considerar nos diferentes contextos. Sublinha e explica, ainda, os motivos de as democracias serem capazes, a médio-longo prazo, de conferir uma resposta mais duradoura e eficaz em momentos de crise sanitária.

\footnotetext{
*E-mail: rcdominguez@ics.uminho.pt

**E-mail: Irodrigues@iseg.ulisboa.pt

***E-mail: land25.jeremy@gmail.com

****E-mail: jari.eloranta@helsinki.fi
} 
Pandemics and spill-over effects: an interview with Vincent Geloso

The year of 2020 brought a scenario of challenges and uncertainties to the globalized world, which many (or most) of us thought we would be prepared to deal with. The rapid spread of COVID-19 and the state of the pandemic have had profound impacts on societies, especially on economic relations. On the other hand, this is not the first event in the history of mankind regarding the development and spread of a disease on a world scale. Within this panorama, many questions have arisen regarding the impact that an event of this magnitude can have on a globalized economy. How do institutions react to a pandemic? How responsive are these institutions? Have we learned anything from past experiences? Is it possible to compare this event with other previous pandemics?

These and other issues were addressed in an interview with researcher Vincent Geloso, Professor of Economics at King's University College (Canada). His research has sought answers to these and many other questions regarding the effect of global pandemics on the economy at other times in history, from a comparative perspective. However, he stresses that there are important differences to be considered in different contexts, and also underlines and explains why democracies are capable, in the medium/long term, of providing a more lasting and effective response in these moments of health crisis.

\section{Guiding Questions for Editorial}

Vincent Geloso is an assistant professor of economics at King's University College. He earned his $\mathrm{PhD}$ in economic history from the London School of Economics. He has published more than 50 articles in journals like Public Choice, Canadian Journal of Economics, Explorations in Economic History, Health Policy \& Planning and British Medical Journal: Global Health. His work can be found at www.vincentgeloso.com.

1. What can economic history tell us about the ways that pandemics can wreak havoc on economies throughout the globe?

Pandemics in the past caused large mortality shocks (as a share of population) and long economic contractions. However, with the exception of an outlier in 1918-19, the trend since the 1857-58 influenza pandemic has been quite favorable.' As a share of populations affected, death rates have been falling and the damages induced by pandemics (as a share of Gross Domestic Product) have also been decreasing. Most interestingly is the chronology of influenza pandemics. While there were seven pandemics between 1700 and 1858, there were only five from 1858 to 2010. The last of these was quite minor. Given that the world economy has expanded 
considerably, that international travel has soared alongside international trade in goods and that population density has increased markedly (i.e. increasing the odds of infections), this is a massive improvement that fails to be noticed by many. In a very strange way, the reason why the present pandemic is so surprising in terms of its impact is that there are no pandemics in people's rearview mirrors. ${ }^{2}$ Thus, unlike people of the early $20^{\text {th }}$ century and $19^{\text {th }}$ centuries, there are few reference points in terms of pandemic-events. Combined, these historical elements suggest that mankind has become increasingly better able to withstand extreme health shocks than in the post.

Now, I must add something of importance: the cost of pandemics (both human and economic) is a function of the disease's features, features of the local population and of institutional settings. The former set (i.e. the disease's features) is easy to understand for everyone: how infectious is it, how deadly is it etc. The second is also pretty evident and we can talk about it in a minute but the last factor is the most important. There is a good connection between health and development: richer societies tend to be healthier societies. There is also a connection between institutional quality (i.e. liberal democracies with rule of law, secure property rights and open markets) and development. That entails that there is a connection between institutions and health. Societies with high institutional quality are going to be able to withstand shocks like COVID better because these institutions make them rich. So, the improvement I mentioned earlier is tied to economic development.

However, that connection is a bit fuzzy. There are some diseases that liberal democracies committed to the protection of individual liberties (of which I count property rights) cannot deal with properly. ${ }^{3}$ Some diseases, especially communicable ones, are particularly aggressive and heavy-handed methods are quite effective in quashing that disease. In other words, there are some diseases that can be fought quite well with coercion. The problem is that the institutions that can deploy such coercion are also unlikely to be liberal democracies with strong constraints on the abuse of individual rights. Such illiberal societies are thus going to enjoy lower mortality from extreme communicable diseases, but that illiberalism is probably going to make them poorer. In the long-run, that matters a lot because economic growth has palliative effects: greater incomes reduce the propensity to suffer from non-communicable diseases (e.g. tuberculosis, nephritis, diarrhea, cardiovascular conditions, lung diseases, cirrhosis, etc.) or less aggressive communicable diseases that require heavy investments in things like water treatment and swamp draining (e.g. typhoid fever, malaria).

2 Beveridge, W. I. (1991), "The chronicle of influenza epidemics", History and philosophy of the life sciences, 13(2), 223.

3 Troesken, W. (2015), The pox of liberty: how the constitution left Americans rich, free, and prone to infection, Chicago, University of Chicago Press. 
These points create a strange paradox that has escaped many. At any given point in time, at any snapshot liberal societies are going to perform poorly in terms of managing an extreme pandemic event like COVID-19. However, they are also going to fare better in terms of economic development and long-term improvements in broadly-defined health outcomes. This is a strange paradox that has escaped many who fail to consider the role of institutions.

The problem, I fear, is that a lot of people are now involved in the debates over the "proper" COVID-19 response and are going about it assuming that they are advisers to benevolent and omnipotent rulers. They fail to consider the rich institutional tapestry in the background. More importantly, they fail to consider that a tapestry is a weaving of many threads that cannot be separated otherwise the whole tapestry unravels. Institutions are like tapestries or, in economic jargon, bundles: you take them as is and accept that you cant pick and choose features. If you want a strong liberal democracy that protects property rights in order to secure economic growth, you cannot have a strong state that use the heavy-handed measures needed to deal with a pandemic. And if you want the state to be strong enough to deal with pandemics, you cannot have the same rate of economic development. Incidentally, that is why there is a strong association between historical prevalence of infectious diseases and the propensity to have authoritarian governments. ${ }^{4}$ Alongside llia Murtazashvili, I also provide evidence of this relationship by showing that the stringency of government policies in the face of COVID is inversely associated with both the Polity Index (measuring political freedom) and the Economic Freedom of the World Index (measuring economic freedom). ${ }^{5}$

2. Given your recent publications on the 1918 flu pandemic, is that pandemic the best comparison to Covid-19 pandemic? Why not other, more modern pandemics such as the SARS outbreak of 2002-04 or even the 1968 Hong Kong flu pandemic?

There are many elements to consider. In terms of human lives lost, COVID-19 is more like the Hong Kong Flu of 1968 or the Asian Flu of 1957. However, in terms of economic costs, there are fewer similarities. The public health responses in 1957 and 1968 were nowhere near what we observe today with COVID-19. There were few school closings and no lockdowns. ${ }^{6}$ Public policy thus limited the economic contraction. The 1918-19 pandemic, however, generated very similar economic consequences. Because it tended to kill prime age workers, the Spanish flu decimated a large

\footnotetext{
4 Murray, D. R., Schaller, M., Suedfeld, P. (2013), "Pathogens and politics: Further evidence that parasite prevalence predicts authoritarianism", PloS One, 8(5), e62275; Pericàs, J. M. (2020), "Authoritarianism and the threat of infectious diseases", The Lancet, 395(10230), 1111-1112.

5 Geloso, V., Murtazashvili, I. (2020), "Can Governments Deal with Pandemics?" Available at SSRN 3671634. 6 Honigsbaum, M. (2020), "Revisiting the 1957 and 1968 influenza pandemics", The Lancet, 395(10240), P1824-1826.
} 
portion of the workforce causing a contraction. Today, because of lockdowns and the need to adjust consumer (e.g. facemasks) and business (e.g. plexiglass equipments) behaviors, COVID-19 caused a similar economic contract to 1918-19. Thus, I would say that 1918-19 is closer to COVID-19 than others in economic terms.

But allow me an important digression here to say that I see in this a massive victory. Few would see a triumph of economic development at first glance but they would be wrong. Thanks to high levels of economic development, we can technically afford lockdowns and other policies that save lives. After all, it is much cheaper (although not cheap per se) to shut down your business for three months when you are in a rich economy with people holding larger wealth stocks than in the past. You can afford lockdowns to save lives. Poorer societies do not have that same luxury. Let me put it differently: if we had had COVID-19 when we were half as rich as we are today (globally speaking), the death count from COVID-19 would be immensely greater. That is because wealth allows us to weather shocks like these better.

3. If, as you argue, liberal democracies are less capable of handling pandemics than more authoritarian nations, why are some liberal democracies better able to handle the pandemic than others? Are there other mechanisms at play here?

Earlier I mentioned that the features of the local population are of relevance. In these I would include things like social trust and population homogeneity. High trust and homogenous populations are substitutes for governments in terms of insuring that certain behaviors are adopted. For example, mask-wearing can save lives. However, some people may free-ride on the efforts of conscientious citizens. If too many free-ride the effectiveness of mask-wearing is diminished. How do you limit that free-riding? There are two ways. The first is that governments impose a mask mandate. The second is that non-state organizations enforce a social norm. The latter is quite effective in my opinion as ostracism is actually part of evolutionary nature. ${ }^{7}$ Ostracizing and stigmatizing free-riders (e.g. by refusing them service, by refusing to talk to them etc.) can lead free-riders to stop free-riding. ${ }^{8}$ The liberal democracies that deal better with COVID-19 are those where these substitutes to state methods are easier to use. These tend to be highly homogenous societies or high-trust societies.

Think about it this way. A society needs to achieve $X$ level of social distancing to minimize the damages of COVID-19. How do you get to $100 \%$ of X? Liberal

7 Kurzban, R., Leary, M. R. (2001), "Evolutionary origins of stigmatization: The functions of social exclusion", Psychological Bulletin, 127(2), 187.

8 Nakamaru, M., Yokoyama, A. (2014), "The effect of ostracism and optional participation on the evolution of cooperation in the voluntary public goods game", PloS one, 9(9), e108423; Maier-Rigaud, F. P., Martinsson, P., Staffiero, G. (2010), "Ostracism and the provision of a public good: experimental evidence", Journal of Economic Behavior \& Organization, 73(3), 387-395. 
democracies with high levels (e.g. Finland, Sweden, Germany) of social trust probably can achieve (and these are hypothetical numbers) $80 \%$ of $X$ without the need for state methods. Societies with low trust (e.g. France) achieve a smaller proportion and they must thus rely on heavy-handed state methods.

\section{What role does institutional flexibility/rigidity play in determining outcomes?}

Further complexifying the paradox that I mentioned earlier is the fact that liberal societies with open economies also suffer less economically than closed economies when a pandemic hit. In a paper published in Contemporary Economic Policy, my friend Jamie Pavlik and I show that greater economic liberty partially mitigated the economic consequences of excess mortality during the 1918-19 pandemic. In other words, the freer an economy was, the less burdensome were the economic damages. ${ }^{9}$

Why would that be? One way to answer this is to imagine that a pandemic changes costs and benefits of certain activities. Those changes make previous configurations of economic resources less valuable. A rearrangement has to occur. In terms of real-world example, think about capital and labour being reallocated from restaurant and services to the manufacture of personal protection equipment. Such a rearrangement is costly though. Its not easy to train workers to new tasks or move capital to new industries. Part of those rearrangement costs are due to the nature of the crisis. Another part is due to regulatory burdens that make it harder for firms to rearrange their activities. The index of economic liberty that Jamie Pavlik and I used captured that part of the rearrangement costs. Areas with higher levels of economic liberty have more flexibility in terms of adjusting their behavior because these extra adjustment costs are not added to the usual costs of pandemics. Thus, the shock for them is shallower and shorter.

It is worth noting that this is consistent with the literature on economic crises and economic freedom. For example, Christian Bjørnskov analyzed 212 economic crises for a wide array of countries since 1993 and considered the possibility that economic freedom - which he took as a measure of institutional flexibility - mitigated the effects of these crises. While he found that economic freedom did not reduce the risk of a crisis, he found that economic freedom was robustly associated with shorter recoveries and smaller peak-to-trough GDP ratios (i.e. economic contractions were shallower). ${ }^{10}$ The current pandemic fits well with his analysis and my own on the 1918-19 pandemic: institutional flexibility is crucially important in dealing with crises.

9 Geloso, V., Bologna Pavlik, J. (2020), "Economic freedom and the economic consequences of the 1918 pandemic", Contemporary Economic Policy.

10 Bjørnskov, C. (2016), "Economic freedom and economic crises", European Journal of Political Economy, 45, 11-23. 
5. In the long run, what are some ways that societies can better prepare for pandemics to reduce their susceptibility?

I think that question is built on a false premise to be honest. It implies that there is a "central mind" that can deal with pandemics risk and management in the future. I dispute this on several grounds.

As I pointed our earlier, pandemics have grown less damaging and less frequent over time in spite of greater connectedness between individuals worldwide which should increase pandemic occurrences. That implies that there must some mitigating forces somewhere. There is an important paper on travel frequency and cross-immunity that provides an answer to this. ${ }^{11}$ By travelling more and more, we expose ourselves frequently to low virulence pathogens. This exposure creates cross-immunity in the sense that it reduces the likelihood of a high-virulence strain spreading easily. That paper points out that because of this mechanism, increasing international travel actually reduced the likelihood of a pandemic. Notice something here, such a mechanism doesn't hinge on a particular government solution. It hinges on no plan by actors. It is an accidental (and fortunate) byproduct of human actions.

And, even more importantly, this gives us a glimpse as to why liberal democracies fare worse in the face of pandemics than authoritarian regimes at any given point in time and why both liberal democracies and authoritarian regimes keep getting better at minimizing the demographic costs of pandemics (as evidenced by the death counts, I mentioned earlier). By letting people free to travel, economically and politically free nations are producing a positive externality for people living in less free countries. Indeed, free nations reduce the risk for unfree nations. In other words, free nations are pulling the cart up the hill for everyone else. For their troubles, they are condemned to perform poorly compared to unfree nations at any point in time even though they are driving general improvements for all.

This last point of mine shows why I think that most of our robustness (some would say antifragility) to pandemic shocks are not driven by conscious plans by bureaucrats and technocrats (not that public health bureaucracies play no role). Rather, most of our robustness is due to less evident forces.

11 Thompson, R. N., Thompson, C. P., Pelerman, O., Gupta, S., Obolski, U. (2019), "Increased frequency of travel in the presence of cross-immunity may act to decrease the chance of a global pandemic", Philosophical Transactions of the Royal Society B, 374(1775), 20180274. 
6. Finally, how do we reconcile economic concerns with medical and moral concerns (i.e. saving lives vs. saving jobs)?

Again, there is a false premise here. You are assuming a single one-dimensional trade-off. Throughout this interview I have recurrently pointed out that there are multiple trade-offs occurring at once. We first trade-off between greater prosperity later and fewer pandemic-related deaths now. That trade-off sets off a second one whereby less prosperity later means greater mortality from diseases that economic growth combats well. A third trade-off is also generated as the institutions that generate prosperity and make us less able to deal with pandemics are also making the pandemics less costly. Then, there is a fourth trade-off as the institutions that generate prosperity, while they make societies less able to deal with pandemics, inadvertently reduce the risks of extreme pandemics occurring in the first place. These are not sequential trade-offs but rather simultaneous. Once we pick one course of action, we settle all four choices at once.

Normatively, I think there is a case to be made for opting in favor of modest responses to pandemics. When I say modest, I do not mean "no action". I mean that we should try as much as possible to rely on private mechanisms to mitigate propagation (as per my social trust example) and when that fails, governments should step in. However, when we let them step in, we should have a propensity to rely on federalist principles that allow government solutions to be decentralized as much as possible. That will tend to allow information about disease response to be generated allowing other local governments to use these multiple information streams to adjust better. This is important because federalism is market-preserving while it allows for a more optimal provision of public goods. ${ }^{12}$ Third, and most importantly, any powers given to governments should come with a sunset clause so that emergency powers are abandoned in totality by a certain date. This combination of approaches, in my view, is the most likely to allow to err on the side of the trade-offs that create the greatest well-being in the long-run.

12 Weingast, B. R. (1995), "The Economic Role of Political Institutions: Market-Preserving Federalism and Economic Development", Journal of Law, Economics, and Organization, 11(1), 1-31; Breton, A. (1970), "Public goods and the stability of federalism", Kyklos, 23(4), 882-902. 